\title{
The long-term price-earnings ratio
}

Article

Accepted Version

Anderson, K. and Brooks, C. (2006) The long-term priceearnings ratio. Journal of Business Finance and Accounting, 33 (7-8). pp. 1063-1086. ISSN 1468-5957 doi: https://doi.org/10.1111/j.1468-5957.2006.00621.x Available at https://centaur.reading.ac.uk/20508/

It is advisable to refer to the publisher's version if you intend to cite from the work. See Guidance on citing.

Published version at: http://dx.doi.org/10.1111/j.1468-5957.2006.00621.x

To link to this article DOI: http://dx.doi.org/10.1111/j.1468-5957.2006.00621.x

Publisher: Blackwell Publishing Ltd

All outputs in CentAUR are protected by Intellectual Property Rights law, including copyright law. Copyright and IPR is retained by the creators or other copyright holders. Terms and conditions for use of this material are defined in the End User Agreement.

\section{$\underline{\text { www.reading.ac.uk/centaur }}$}

\section{CentAUR}

Central Archive at the University of Reading

Reading's research outputs online 
This is the authors' accepted manuscript of an article published in the Journal of Business Finance and Accounting. The definitive version is available at www3.interscience.wiley.com 


\title{
The Long-Term Price-Earnings Ratio
}

\author{
Keith Anderson, ISMA Centre, \\ University of Reading
}

\author{
Chris Brooks, ‘, Cass Business School, \\ City of London
}

\begin{abstract}
The price-earnings effect has been thoroughly documented and is the subject of numerous academic studies. However, in existing research it has almost exclusively been calculated on the basis of the previous year's earnings. We show that the power of the effect has until now been seriously underestimated due to taking too short-term a view of earnings. Looking at all UK companies since 1975 , using the traditional $\mathrm{P} / \mathrm{E}$ ratio we find the difference in average annual returns between the value and glamour deciles to be $6 \%$. This is similar to other authors' findings. We are able to almost double the value premium by calculating the P/E ratio using earnings averaged over the previous eight years.
\end{abstract}

\section{Introduction}

The ratios of a stock's current price to its earnings over the last company year (historical P/E) and to analysts' consensus forecast earnings for this year (prospective P/E) are widely quoted statistics. The price-earnings effect was the earliest described asset pricing 'anomaly' even before the capital asset pricing model (CAPM) itself was formulated by Sharpe (1964). A large body of academic work has demonstrated the effect and has attempted to decide whether it is real or a proxy for other factors. ${ }^{1}$ The first study demonstrating the P/E effect was by Nicholson (1960), who concluded that 'The purchaser of common stocks may logically seek

\footnotetext{
* Corresponding author. Faculty of Finance, Cass Business School, City University, 106 Bunhill Row, London EC1Y 8TZ, UK. t: (+44) (0) 207040 5168; f: (+44) (0) 207040 8881;

e-mail C.Brooks@city.ac.uk.We would like to thank an anonymous referee for very helpful comments on a previous version of this paper; the usual disclaimer applies.

${ }^{1}$ See, for example, Nicholson (1960 \& 1968), Basu (1975 \& 1977), Ball (1978 \& 1992), Jaffe, Keim \& Westerfield (1989), Fuller, Huberts \& Levinson (1993), Lakonishok et al. (1994), and Dreman (1998) to mention just US studies.
} 
the greater productivity represented by stocks with low rather than high price-earnings ratios.' Basu (1975) and (1977) generally confirmed Nicholson's results.

The PE effect has defied rational explanation. Ball (1978), while conceding the apparent existence of such effects, considered various possible explanations for this anomaly, including systematic experimental error, transaction and processing costs, and a failure of Sharpe's twoparameter CAPM model. Fuller, Huberts and Levinson (1993) re-examined Ball's (1978) argument by using a comprehensive multi-factor model that allowed for systematic risk (beta), 55 industry classification factors and 13 other explanatory factors for 'risk' such as earnings variability, leverage and foreign income. They again found higher returns for low P/E stocks from 1973-1990, but the factors included in the model did not account for the superior low $\mathrm{P} / \mathrm{E}$ returns.

Banz and Breen (1986) criticised previous studies into the size and P/E effects as suffering from two major biases: ex-post-selection bias and look-ahead bias. They eliminated these factors by amassing their own database from the COMPUSTAT tapes for 1974-81 that accurately reflected the companies in existence and the data available to investors at that time. Their conclusion was that although a company size effect persisted, the P/E effect was no longer significant, i.e. that the data biases had created the apparent P/E effect. Jaffe, Keim and Westerfield (1989) considered the January effect as well as the size and P/E effects. They found that the conflicting results of earlier studies could be ascribed to time-variation in the power of the different effects.

Lakonishok, Schleifer and Vishny (1994) ('LSV' hereafter) defined value strategies as buying shares with low prices compared to some indicator of fundamental value such as earnings, book value, dividends or cash flow. They divided firms into 'value' or 'glamour' stocks on the 
basis of past growth in sales and expected future growth as implied by the current P/E ratio. LSV argued that value strategies provide higher returns because they exploit the sub-optimal behaviour of investors. They found little, if any, support for the view that value strategies were fundamentally riskier. Value stocks outperformed glamour stocks quite consistently, yielding particularly strong abnormal returns during market downturns. However, Fama and French (1993 and 1996) found that value stock anomalies could be successfully explained by a three-factor model involving market returns, size and book to market value. But unlike the CAPM, there was no theoretical underpinning offered as to why these factors and not others should be important.

The P/E effect has been observed in many stock markets, ${ }^{2}$ although there are considerably fewer studies investigating the existence and possible justifications for a value effect in the UK. Levis (1989) was the first such study, finding strong results in favour of a value premium. Levis and Liodakis (2001) focused on ascribing the source of the value anomaly to either investors' naive extrapolations of past sales and earnings growth, as put forward by LSV, or to systematic errors in analysts' forecasts of long-term growth. They used data on 3,131 non-financial companies with only a single class of share between 1968 and 1997. By looking at EPS growth for five years both before and after portfolio formation, they showed that companies in the lowest P/E decile experienced low EPS growth over the five years prior to portfolio formation but improved growth thereafter. EPS growth exhibited mean reversion. Thus the anomalies could be ascribed to prior losers becoming winners and vice-versa, as suggested by De Bondt and Thaler (1985). However the pattern of growth did not fit the naive extrapolation hypothesis of LSV. Instead, Levis and Liodakis used I/B/E/S earnings forecast

\footnotetext{
${ }^{2}$ In addition to the above research, countries for which P/E effect studies have been carried out include: thirteen countries around the world (Fama and French (1998)); the UK (Levis (1989); Gregory et al. (2001); Levis and Liodakis (2001)); the UK and several European countries together (Brouwer et al. (1997); Bird and Whitaker (2003)); Holland (Doeswijk (1997)); Finland (Booth et al. (1994)); Japan (Aggarwal et al. (1990); Chan et al. (1991); Cai (1997); Park and Lee (2003)); Taiwan (Chou and Johnson (1990)); New Zealand (Chin et al. (2002)).
} 
data to show that positive surprises have a large effect on value stocks and a small effect on glamour stocks, and vice-versa for negative surprises.

Previous research has, to the best of our knowledge, always used the same approach to calculating the $\mathrm{E} / \mathrm{P}$ (the inverse of the $\mathrm{P} / \mathrm{E}$ ratio): the previous year's earnings, divided by the share price at the time of portfolio formation. However, there is no reason why only earnings from the previous year should be relevant in valuing companies. As Campbell and Shiller (1988) state, annual earnings are quite noisy as a measure of fundamental value. The concept of 'value' may well be better captured by focusing on permanent rather than transient earnings. We have been unable to find any previous academic research into whether knowledge of earnings of previous years will improve the ability of the P/E ratio to predict future returns on individual shares. Graham and Dodd (1934, p.452) recommended the use of average earnings over a period of at least five years and preferably over seven to ten years, to give the analyst a more reliable view of the true value of a company. Yet their conjecture does not seem to have been tested by any academic research. Campbell and Shiller (1988) and Shiller (2000) appear to be the only existing investigations into the value of multi-year earnings averages. They examined earnings over the stock index as a whole, however, rather than at the level of individual companies with reference to the P/E effect.

We find that adding more years of earnings history increases the power of the P/E ratio to predict returns, although this does not happen monotonically. Using eight years of earnings rather than one, the difference between the returns of the glamour and value deciles is almost doubled. The simplest approach to enhancing the usefulness of the E/P ratio is to assign stocks to value and glamour portfolios using earnings averaged over two to eight years. However, equal weights are not necessarily optimal in forming a P/E statistic that is the most efficient predictor of returns. We investigate some alternative and intuitive weighting systems. 
We also calculate the predictive value of individual past years of returns. The best weighting we find is from adding the earnings from last year to the earnings from eight years ago and ignoring the intervening six years. This is perhaps due to the low correlation between the earnings from these two years. Our search is, however, not exhaustive.

Finally, we attempt to deal with three possible criticisms of our approach. Using weights derived from a regression across our whole time period may fairly be criticised as suffering from a look-ahead bias. In order to investigate whether our results would be robust to the use of different years or using a different number of years of data, we employ rolling five-year periods. We find that our optimum weighting, or something very similar, has been the optimum over most five-year periods during the past twenty years. We also calculate the effect of bid-ask spreads on returns and show that transactions costs can only account for a small proportion of the difference in returns between the value and glamour deciles. Finally we investigate whether the trades of typical investors would cause liquidity problems for small company shares.

The remainder of this paper proceeds as follows. Section 2 describes the methodology employed in the calculations of long-term P/E ratios and decile portfolio returns. Section 3 presents the decile returns using the different lengths of earnings histories, where the past years of earnings are all equally weighted. Section 4 uses t-tests, standard deviations and Sharpe ratios to examine the significance of the differences in returns. Section 5 investigates the usefulness of various weighting schemes for the past earnings figures. Section 6 calculates the effects of the bid-ask spread on decile returns and further examines the riskiness of longvalue-short-glamour strategies. It also considers whether the stocks involved are likely to be sufficiently liquid. Section 7 presents a portfolio illustration. Section 8 concludes. 


\section{Data Sources and Methodology}

Initially, we collated a list of companies from the London Business School's 'London Share Price Database' (LSPD) for the period 1975 to 2003. The LSPD holds data commencing 1955 , but only a sample of one-third of companies is held until 1975. Thereafter, data are held for every UK listed company. We therefore only employ data from 1975. We excluded financial sector companies including investment trusts and companies with more than one type of share - for instance, voting and non-voting shares. Apportioning the earnings between the different share types would be problematic.

Earnings data are available on LSPD, but only for the previous financial year. We therefore used Datastream to collect all other series, as this service is able to provide time series data on most of the statistics it covers, including earnings. A four-month gap is allowed between the year of earnings being studied and portfolio formation, to ensure that all earnings data used would have been available at the time. We therefore requested for each company as at $1^{\text {st }}$ May in each year 1975-2003, normalised earnings for the past eight years, the current price and the returns index on that date and a year later.

A common criticism of academic studies of stock returns is that the reported returns could not actually have been achieved in reality, due to the presence of very small companies or highly illiquid shares. In an attempt at least to avoid the worst examples, we excluded companies if the share mid-price was less than $5 \mathrm{p}$. We also excluded the lowest $5 \%$ of shares by market capitalisation in each year. We checked whether this removal of "micro-cap" and penny shares had a significant effect on returns. Penny shares and micro-caps did indeed contribute to returns, although this contribution was across all deciles, not just for value shares. Average returns were $1-1.5 \%$ higher when all companies are included, across all deciles and holding 
periods. An arbitrage strategy that is long in value companies and short in glamour companies would therefore be largely unaffected by the exclusion of very small companies and of penny shares. In Section 7 we also examine the impact of transactions costs, which are likely to be larger for small firms. A further criticism of many studies is that they do not deal appropriately with bankruptcies. Companies that failed (i.e. were bankrupted) during the year are flagged in the LSPD. In such cases, we set the price manually to zero, as in Datastream it often becomes fixed at the last traded price. We thus assumed a $100 \%$ loss of the investment in that company in such cases.

We calculated up to eight E/P statistics for each company/year return, by dividing the sum of the earnings over the previous one to eight years by the current stock price:

$$
E P n_{i}=\frac{\sum_{j=1}^{n} E P S_{i j}}{n P_{i}}
$$

where $E P S_{i j}$ is the normalised earnings per share for company $i$ for $j$ years ago, $P_{i}$ is the current price of company $i$ and $n$ is the number of years of earnings used in the EPn calculation. As earnings would be expected to rise on average over time with inflation, there is a small implicit weighting of the later earnings in favour of the earlier ones, in cases where more than one year of earnings is used. Where Datastream reported a company as having a zero EPS, i.e. normalised earnings were negative, or there was no EPS recorded for one or more previous years, EPn for those year(s) could not be calculated. ${ }^{3}$ We therefore had to exclude the company from further analysis for that EPn. Due to these factors, the number of companies for each EPn calculation gradually reduces as the EPS figure becomes unavailable for years further into the past, from 40,000 initially to 16,000 that have a full eight years of positive earnings history.

\footnotetext{
${ }^{3}$ Unfortunately, Datastream records any zero or negative normalised earnings as zero, and there is therefore no way to distinguish between the two.
} 
We then sorted shares by EPn, grouped them into deciles within each year and calculated the returns for each decile for the subsequent year as if it were an independent portfolio. In fact we calculated returns for holding periods of up to eight years, but the results are usually qualitatively unaltered from those for one-year returns so in most cases we do not report them. Where we used a weighted average of past earnings, the E/P for the $i^{\text {th }}$ company/year return was calculated as

$$
E P_{i}=\frac{\sum_{j=1}^{8} W t_{j} E P S_{i j}}{\sum_{j=1}^{8} W t_{j}}
$$

where $W t_{j}$ is the weight for the earnings for the $j^{\text {th }}$ year and $E P S_{i j}$ is the normalised earnings per share for company/year return $i$ from individual past year $j$ (one to eight years previously). The right-hand side is thus a weighted average of the past eight years of earnings divided by the current share price. The weights vary according to the weighting scheme and are explained in Section 3.

Section 6 considers the effect of the bid-ask spread on the decile returns. Bid and ask prices were first recorded on Datastream in 1987 but for the majority of companies are only available from 1991. Where the actual bid-ask spread was available for that company on that day we used it, calculating the returns after allowing for spread losses. To cater for companies for which bid and ask prices were not available, we divided companies into 20 categories by market capitalisation within each year and calculated the average bid-ask spread for each category. Companies for which bid-ask spreads were not available then used the average bidask spread for their category. We applied no transaction cost where a share remained in a 
particular decile portfolio for more than one year, since selling and re-purchasing the share would be unnecessary.

\section{Returns for the Long-Term P/E Ratio}

In this section we report the main initial results of the investigation, showing the average portfolio returns by $\mathrm{P} / \mathrm{E}$ decile. We present the results first in Table 1, showing the distribution of returns after using the EP1-EP8 statistics (i.e. based on 1-8 years of earnings history) to sort companies into decile portfolios. The difference in returns does increase as one takes more years of past earnings into account, but not monotonically: in particular there is a dip for EP2 and EP3, so that calculating P/E ratios using the previous two or three years of earnings is less rewarding than using only the previous year's earnings. This is reminiscent of the pattern of reversals identified by De Bondt and Thaler (1985), who noted an initial underperformance of their loser portfolios, but outperformance in years two and three. In the current case, high earnings two and three years ago tend to indicate poorer performance in the future. The value premium when using four or five years of earnings is quite similar to that obtained using only the previous year's earnings, but the superiority of using six years or more is clear. Using a full eight years of past earnings, which is the cut-off point for our database, gives a value premium almost twice that of EP1.

Panel A of Table 1 uses all the available company/year returns to compute the EP. This results in the number of companies included in the deciles decreasing monotonically from left to right across the table, as we require an increasing number of years of earnings history to compute the EP. In order to ensure that the results are comparable across EPn for $n=1,8$, we recomputed the EPn in Panel B of Table 1 using only firms with a full eight years of earnings 
history throughout ${ }^{4}$. Requiring firms to have a full eight years of earnings history leads to higher returns for the value decile but little change in the returns for the growth decile, so that the long-value-short-growth arbitrage strategy returns are increased by around 2-3\% for EP1 through to EP7. Figure 1 compares the returns using EP1 as the basis of assignment of companies to deciles, to using EP8. Returns for the one-third of shares with high P/E's are poorer using EP8 compared to EP1. D8 and D9 give quite similar returns, but the extreme value decile for EP8 gives returns a full 3\% better per year than the EP1 value decile.

Table 2 examines the impact of employing longer holding periods than one year on the size of the value premium. The results suggest that the arbitrage strategy returns are fairly stable across holding periods of 1 to 4 years but decline thereafter. This reduction in performance as the holding period increases beyond four years is because the best returns for low $\mathrm{P} / \mathrm{E}$ companies are in the early years. On the other hand, the high $\mathrm{P} / \mathrm{E}$ company returns peak sharply in the first year, but actually get slightly worse over long holding periods. This may be due to companies with share price momentum having high prices and thus high P/E's. As Jegadeesh and Titman (1993) showed, the momentum effect peaks over a twelve-month holding period but declines rapidly thereafter.

\section{Significance Tests}

In this section we investigate whether the more extreme returns observed from using longer periods of earnings represent a statistically significant improvement. We also look briefly at the standard deviations and Sharpe ratios of the portfolios of one-year returns, to determine whether it is reasonable to view the higher returns as merely a fair payment for taking on greater risk.

\footnotetext{
${ }^{4}$ The results for EP8 are therefore identical across Panels A and B of Table 1.
} 
We conducted paired sample, two-tailed $t$-tests to determine whether using two to eight years of past earnings as the rule to assign companies to deciles gave returns different to those using EP1. For deciles 1 to 9 there were no more significant results than would be expected from chance alone, so we do not report these. However, there were significant results for the value decile. These are shown in Panel A of Table 3. When using EP6-EP8 as the statistic for assigning companies to deciles there are significantly superior returns for every holding period longer than one year. For the value decile alone, insisting that value companies have six or more years of positive earnings history significantly increases returns. This leads us to the important conclusion that value investors using a $\mathrm{P} / \mathrm{E}$ filter should insist on a long history of positive earnings for the companies in their portfolio. There is however no significant evidence that it is of use to mainstream investors.

We also conducted $t$-tests to determine whether the D10-D1 value premium is significantly different for EP2 through to EP8 as compared to EP1. The results are shown in Panel B of Table 3. Although using longer periods of earnings gives no significant results for a one-year holding period, the level of significance increases as the holding period and number of years taken into account increases, until for a holding period of eight years EP8 is statistically significantly better at discriminating returns than EP1 at the $0.1 \%$ level. In results not reported, we also regressed the annualised value premium against the number of years of earnings taken into account ${ }^{5}$. The number of years over which the earnings are measured did not significantly affect the value premium for one-year holding periods, but it was significant at the 5\% level for a two-year holding period. This significance increased progressively to the $0.1 \%$ level for an eight-year holding period.

\footnotetext{
${ }^{5}$ We thank an anonymous referee for proposing this alternative view of our significance tests.
} 
Figure 2 shows the standard deviation of returns for a one-year holding period. There is a marked V-shape, with the lowest standard deviations being for deciles four and five. Anecdotally, it is widely believed that there are years when investing in value shares gives the best returns, but there are other years such as 1999-2000 when glamour stocks are superior. Possibly, the shares that fall into the middle deciles give more consistent returns over the years, even though their returns in absolute terms are not as good as those for the value decile. The very high standard deviation of returns for the glamour decile under EP1 is noticeable. This reduces gradually as one moves towards the back of the chart, so that the standard deviation for the glamour decile is one-third less when using EP8 than when using EP1. For the value decile, on the other hand, the standard deviations are almost the same running from EP1 to EP8, even though the returns for EP8 are almost double those for EP1.

In order to decide whether the higher returns are sufficient compensation for their higher variability, we look at the Sharpe Ratios of the portfolios. These are calculated as the excess return of the portfolio over the risk-free rate, divided by the standard deviation. We used the three-month Treasury bill rate as the proxy for the risk-free rate. The Sharpe ratios for a oneyear holding period can be seen in Figure 3. The proportion of excess returns compared to standard deviation increases consistently as one moves from the glamour to the value decile. The Sharpe Ratio is particularly bad for the EP1 glamour decile and particularly good for the EP7 and EP8 value deciles. These deciles offer a ratio of excess returns to standard deviation more than twice as high as the EP1 glamour decile. Clearly the higher returns for the EP8 value decile cannot be ascribed to the investor having taken on greater risk. 


\section{Optimal Weights for the Long-Term P/E}

So far, we have used equal weights for each year of past earnings. There is no particular reason why this should produce the best resolution, i.e. the largest difference in annual returns between the glamour and value deciles. A priori, one would expect the most recent year's earnings to be more useful in predicting future returns than more historically remote years of earnings. Unfortunately, a full examination of the universe of possible weighting rules is not possible due to the sheer number of possibilities ${ }^{6}$. We instead look initially at some other examples of weights that are simple and justifiable, such as monotonically increasing and decreasing weights and the results of a linear regression of the eight year EP's against oneyear returns. Next we look at the predictive powers of individual years of past earnings. We then consider how incorporating additional years of earnings improves the predictive powers of the E/P statistic. Finally, to try to ensure that the analysis does not suffer from look-ahead bias, we test the best weighting rules against rolling five-year periods of returns to see which rules would have performed best over various sub-periods within our sample.

In this section, we used only the 16,000-company/year returns that have positive normalised earnings for each of the past eight years. This subset of the data should contain the most information that the P/E has to offer about future returns. Note that in order to assign weights, we are now considering individual past years of earnings divided by the current share price, not the sum of the past $n$ years. EP8 has as its numerator the sum of the last eight years of earnings; EPM8 (i.e. EP minus eight) has as its numerator the individual earnings figure from eight years ago. The denominator is the same for both: the share price as at the date of portfolio formation.

\footnotetext{
${ }^{6}$ With eight statistics and varying the weight of each from -10 through 0 to +10 , for example, the number of combinations for which returns would have to be calculated is $\left(\left(21^{\wedge} 8-1\right) / 2\right) \approx 19$ billion.
} 


\section{Returns using Individual EPMn's}

Before looking at more complex weighting schemes, we first test each EPMn on its own as a predictor of returns so as to get a better appreciation of their individual predictive power. The results are shown in Table 4. It can be seen that EPM5 through to EPM8 are, individually, better discriminators of future returns than EP1. This is an important and counter-intuitive result: calculating the $\mathrm{P} / \mathrm{E}$ ratio as the ratio of the current stock price to the earnings from five, six, seven or eight years ago gives a better predictor of returns than the usual P/E ratio. This may be more of a comment on the poor predictive power of EP1 than a serious recommendation to predict returns using these earnings that are more remote in time.

EPM2 and EPM3 are on the other hand particularly poor predictors of returns. This may be a facet of the reversals of returns over a two- or three-year period observed by De Bondt and Thaler (1985), where for the first year previous winners continued to do well but over a twoor three-year timescale previous losers showed strong recoveries. In this case the losers are not identified directly but by having high E/P's. The poor performances of EPM2 and EPM3 and to a lesser extent EPM4 are largely due to the good performance of their glamour deciles, which outperform decile 2 by $2-3 \%$ in each case. The outperformance of the glamour deciles is partly due to companies that would normally fall into the value deciles having one bad year, as pointed out by LSV. For example, there were 48 company/year returns that fell into EPM3's glamour decile because they showed particularly weak earnings three years ago, when on the basis of an equally weighted average of the other seven years of earnings they should have been placed in the value decile. These companies showed average one-year returns of $41.6 \%$. 


\section{Returns from Simple Weighting Schemes}

The simplest possible weighting scheme is equal weights, returns for which we already reported in Section 3. In addition, we tried linearly increasing weights, so that the most recent year of earnings has the greatest weight, and weights that increase according to an inverse square law, so that the most recent year has an even heavier weight. So as to show the relative value of more recent years of earnings, we also calculated returns for mirror-image weighting schemes that decrease linearly or according to the inverse square law. According to our $a$ priori expectations these should perform poorly, since we expect the most recent earnings to have the most predictive power. We report decile returns for these weighting schemes in columns 1 to 5 of Table 5 .

The $11.62 \%$ value premium seen in Table 5 for equal weights is the standard against which all other results should be measured. If other weighting régimes cannot outperform this simple system by a worthwhile margin then the constant weights should be retained. Of the other four weighting systems, the reverse weights are best with straight-line reverse weighting giving the highest value premium of $12.17 \%$. Both the reverse weighting systems provide resolutions considerably superior to those of the 'forwards' weighting systems. This is contrary to the a priori expectation that more recent earnings would be more relevant to predicting returns than earnings further back in time. The explanation can be found in the resolutions achieved by the individual EPMn's reported above: the particularly poor predictive power of EPM2 and EPM3 means that any scheme that weights these two heavily will perform poorly. The even heavier weight given to EP1 under any 'forward' weighting is not enough to counterbalance this weakness. 


\section{Predicting Returns from the EPMn with a Linear Regression}

In order to examine whether a linear regression yields better weights of the historical earnings, we ran a regression against the 16,000 company/year returns that have positive earnings for each of the last eight years. We expected it to give us an optimal weighting system that would outperform any of the resolutions seen so far. The model is

$$
\begin{aligned}
& \operatorname{Rtn} 01_{i}=\beta_{0}+\beta_{1} E P 1_{i}+\beta_{2} E P M 2_{i}+\beta_{3} E P M 3_{i}+\beta_{4} E P M 4_{i} \\
& +\beta_{5} E P M 5_{i}+\beta_{6} E P M 6_{i}+\beta_{7} E P M 7_{i}+\beta_{8} E P M 8_{i}+u_{i}
\end{aligned}
$$

where $R \operatorname{tn} 01_{i}$ is the one-year holding period return for company-year $i, E P 1$ is the EP calculated on the basis of the previous year's earnings, $E P M j_{i}$ is the EP calculated from the earnings two through to eight years ago and $u_{i}$ is a disturbance term.

The coefficients from the regression are shown in the top part of column 6 in Table 5. EP1, EPM3 and EPM4 are significant at the $0.1 \%$ level, EPM2 is significant at the 5\% level, but EPM5-EPM8 are not significant. EP1, in accordance with our expectations, has twice the weight of EPM2-EPM4. Earnings more than four years old have small but positive parameter values. However, although EPM2 and EPM3 are positive indicators of returns when taken alone, when combined with the information available in the other EPM $n$ they have significant negative coefficients, entirely contrary to what one would expect.

Looking at the last row of Table 5, the resolution of $11.77 \%$ achieved by the linear regression is only fractionally better than the $11.62 \%$ achieved by using equal weights. It is poorer than the resolution of $12.17 \%$ for reverse linear weights. This approach does not therefore give optimal weights even when using all of the data in a single regression. This result is slightly surprising for it suggests that the equal weighting is hard to improve upon even with perfect foresight concerning the optimal weights to use. This may be due to some degree of collinearity between adjacent EPM figures. It may also be that the regression is a linear one 
but the portfolio approach to evaluating the power of the price-earnings ratio is inherently non-linear ${ }^{7}$.

\section{Returns using Two EPMn's}

Considering the failure of the linear regression to yield a superior resolution, does combining two or more of the EPMn yield better results than the individual EPMn's? EP1 is the standard figure for the P/E ratio. As such it should presumably be included in any weighted average of EPMn's. Table 6 shows the resolutions available from combining EP1 with each of the other EPMn figures. We make no attempt to attach fractional weights; the figures for the earnings last year and for the earnings $n$ years ago are simply added together, then divided by the current share price. The resolution offered by the best weighting scheme found so far, the reverse linear weights, is bettered by using EP1 plus EPM8. Also of note is that EP1 plus EPM2, and EP1 plus EPM3, give a poorer resolution than EP1 alone. EPM2 and EPM3 when included with EP1 have taken away value from the combined statistic, even though when used alone EPM2 and EPM3 give a small but nevertheless positive resolution figure.

Some explanation of the observed resolutions of the different EPMn pairs is offered by looking at their correlations in Table 7. Correlations between adjacent years of EPMn figures are particularly high, in the region 0.7 to 0.8 . It is therefore not surprising that if an EP statistic is created by adding EPMn figures from adjacent years it adds little resolution to the underlying EPMn values. The low 0.28 correlation between EP1 and EPM8, presumably due to their remoteness in time to each other, may also explain the high resolution found by adding the two values together ${ }^{8}$.

\footnotetext{
${ }^{7}$ We thank an anonymous referee for proposing this explanation.

${ }^{8}$ We also examined triple combinations of the EPMn figures. Adding in a third EPMn figure to EP1 and EPM8 reduced the one-year holding period resolution of the combined statistic in every case except using EPM4. Here, the average returns were increased by $0.4 \%$, and Occam's Razor therefore suggests that the simple (EP1+EPM 8$)$ statistic be adhered to, rather than adding in a third EPMn.
} 


\section{Data Mining?}

The linear regression may fairly be said to suffer from look-ahead bias, in that it takes weights derived from a regression on our whole dataset then tests its efficacy over the same 1975 to 2003 period. Even using this look-ahead bias it is unable to beat some of the simpler weighting schemes. Although these simpler schemes do not suffer from look-ahead bias, they have also so far only been tested against the entire 1975-2003 period.

We initially calculated the resolutions of some of the best rules for each of the 29 years to see whether any one rule predominated. These results are summarised in Table 8. The 'EP1+EPM8' rule gave the best resolution for ten of the twenty-nine years. The 'EP1+EPM4+EPM8' rule gave a slightly higher average resolution but with a higher standard deviation and was only best in four years. The linear regression weights gave the best resolution in only six years.

We next considered whether the best statistic would have been different had the data been collected at another time using a different number of years. Any combination of base year and any number of retrospective years could be used, but in order to give some comparability to the results, we selected a rolling five-year period. This yields a sufficiently large number of company/year returns for each five-year period (at least 2,300). Figure 4 plots the rolling (overlapping) five-year average resolution for each of the simple weighting schemes in Table 8, excluding the linear regression. The resolution in Figure 4 is then the average of the five individual year resolutions. The most visible conclusion is that the resolutions follow each other quite closely whichever weighting system is chosen. 1982 and 1999 were low points for any value-glamour arbitrage strategy. Indeed in 1998 and 1999 every weighting system had provided negative returns to the arbitrageur over the previous five years. However, since then 
there has been a resounding resurgence similar to that seen in 1982-1985. By 2003, average resolutions over the previous five years exceeded $20 \%$ per year. Over the whole period, no one weighting system predominates, but adding the previous year's earnings to the earnings eight years ago is often best. Ascending weights, that might $a$ priori have been thought to be the most reasonable as they assign the most weight to the most recent $\mathrm{E} / \mathrm{P}$, are often the worst amongst the weighting rules charted. The rolling five-year returns at least give some confidence that much the same conclusion would have been reached had our investigation been carried out at any time over the past 29 years.

\section{The Effect of the Bid-Ask Spread, Risk and Liquidity}

It is often suggested that the effectiveness of value-based investment strategies will be much reduced once transaction costs are taken into account. Although commission charges applicable to the deciles will be similar, since they consist of similar numbers of shares and are rebalanced over the same periods, the effect of the bid-ask spread will be different between the deciles ${ }^{9}$. As shown below, low P/E firms tend to be smaller companies that have larger spreads. How much does allowing for the effect of losses from the bid-ask spread reduce the difference in returns between the deciles? A related possible problem is that smaller companies are likely to have poorer liquidity. Will the trades of a typical investor cause liquidity problems for the shares of small companies that are concentrated in the value decile? To determine the impact of transactions costs on strategy returns, we divided companies into 20 categories based on market capitalisation, calculated the spreads as they affect one-year returns and averaged them over each market value category. The results are

\footnotetext{
${ }^{9}$ Investors must also pay a $0.5 \%$ UK tax known as stamp duty on all share purchases. This will reduce returns by up to $0.5 \%$ per annum, depending on stock turnover within each decile. Since it will affect the deciles roughly equally, we do not incorporate it into our calculations.
} 
shown in Table 9 and Figure 5. The spread costs shown in Figure 5 range quite smoothly from $8.2 \%$ for the smallest $5 \%$ of companies, to only $0.95 \%$ for the largest $5 \%$.

The changes to compound annual returns after allowing for transaction costs using annual rebalancing are shown in Table 10. Returns for each decile are shown, with and without the bid-ask spread taken into account in one-year returns. Also shown are the average market value categories for each decile. The value premium is reduced by $2.6 \%$ and the returns on the value decile reduce by $4.18 \%$ from $28.95 \%$ to $24.77 \%$. The fact that smaller companies tend to have lower P/E's and therefore tend to appear in the value decile can be seen by looking at the 'MV Category' column. The value decile has an average MV category of 6.01 , which is equivalent to an average market capitalisation of $£ 44 \mathrm{~m}$ in 2003 . This rises to MV category $11.65(£ 190 \mathrm{~m})$ for the glamour decile.

Overall, the reduction in returns caused by the bid-ask spread is serious but not catastrophic to a P/E-based strategy. If shares were sorted into deciles purely by size, we would expect spreads to reduce the value premium by the difference in bid-ask charges for MV categories 1 and 2 compared to MV categories 19 and 20. From Table 9, this is $6.43 \%$. In fact it is reduced by $2.6 \%$, or only one-fifth of the value premium. This is partly because the glamour and value deciles are not made up exclusively of large and small shares respectively, and partly because not all shares are sold and re-bought annually. If shares 'roll over' from one year to the next because they appear in the same decile this reduces the spread costs. It is clear that the bid-ask spread can only account for a small proportion of the difference in returns between the value and glamour deciles.

The final column of Table 10 shows the CAPM betas for each decile portfolio. These betas are very similar across the deciles, with slightly lower betas for the value decile than the 
growth decile. We thus find that, in common with previous studies, the value premium cannot be rationalised by risk in the sense of the CAPM.

In Table 11 we consider whether book value-to-price and firm size would be equally useful discriminators of company stock performance. The table presents the extreme decile returns for stocks separately sorted using EP1, EP8, book value-to-price and market capitalisation for investment horizons of 1 to 8 years. We recalculate the EP1 and EP8 results since the analysis is now conducted on a smaller sample of 8,300 company-years for which book values are available. Incorporating eight years of earnings information into the EP statistic rather than just one year again results in a stronger value premium for this sub-sample of companies. There is also a clear size premium, with the smallest $10 \%$ of companies yielding stock returns around $12 \%$ higher than those of the largest $10 \%$ of companies for holding periods of up to 3 years. For these shorter investment horizons, the size premium is similar in magnitude to the EP8 value premium. However, the size premium would be the most seriously affected by the differential bid-ask spreads between larger and smaller companies. Book value-to-price, the value measure favoured by Fama and French, is a stronger discriminator of returns that the traditional $\mathrm{P} / \mathrm{E}$ ratio, but weaker than the modified $\mathrm{P} / \mathrm{E}$ ratio that employs a longer history of earnings.

We also checked whether the limited liquidity of some shares would have caused difficulties for investors. Datastream has daily turnover figures for most companies starting in 1987 . We assumed a representative private investor with $£ 50,000$ to invest in 2003 and a hedge fund with $£ 20 \mathrm{~m}$. We deflated these portfolio values going backwards in time by the average market return. For example, in 2002-2003 the average return was unusually negative at $-15.22 \%$, so our private portfolio value for 2002 was larger at $£ 58,975$. Table 12 shows the median number of days of turnover represented by the trades of these two sample investors, using EP1 and 
EP8 to assign companies to deciles. For the private investor, the trades conducted usually represent only a small proportion of a day's turnover in the shares, so he will rarely face liquidity problems. Investing in the glamour decile will also present no liquidity problems for the hedge fund even though its trades are 400 times as large, because the glamour decile consists mostly of large companies. Where problems are likely to occur is the value decile because small companies are concentrated here. For this decile the median trade represents 3.37 days of turnover using EP1, so even a small institutional investor would often have to spread the required trades over several days to avoid moving the market adversely. However since the strategy is not particularly time-dependent, this is not likely to be a major issue. The liquidity problem is slightly worse using EP8, with a median trade size of 4.54 days' turnover.

\section{Portfolio Illustration}

The following example shows the impact on returns of optimising the weights of the past eight years of earnings, compared to the original P/E. We calculated the performances of the value and glamour deciles identified using the (EP1+EPM8) statistic and compared them to the returns for the deciles calculated using the traditional P/E ratio EP1. All portfolios use annual rebalancing. The final values and compound returns are shown in Table 13 and the values of the four portfolios are shown graphically in Figure 6. The new value decile as calculated using (EP1+EPM8) outperforms the value decile from EP1 and the new glamour decile underperforms, so that the previous deciles are bracketed by the new deciles. Our use of a logarithmic scale in Figure 6 does not give a visual impression of dramatic outperformance or underperformance. However, over 29 years the compounding effect results in a new value decile worth almost twice as much as the old value decile, and a new glamour decile worth two-thirds the old glamour decile. The value premium is thus considerably enhanced. 


\section{Conclusion}

Graham and Dodd (1934) suggested that multiple years of earnings should be used to assess the long-term value of a company. Although using multiple years of earnings seems a very natural way of measuring fundamental value, we are not aware of any previous investigations into whether several years of earnings are more useful in predicting returns than one year. Our results suggest that a $\mathrm{P} / \mathrm{E}$ calculated from multiple years of earnings is a better predictor of returns than the traditional one-year P/E. An eight-year average is twice as effective. However the difference between returns from the glamour and value deciles does not increase linearly as more past years are added into the calculation. Earnings from two or three years ago are particularly poor predictors.

We examined several plausible weighting rules for the past years of earnings, using the subset of companies with a full eight years of positive normalised earnings. The individual earnings figures from five, six, seven or eight years ago, divided by the current share price, are better predictors of returns than the traditional P/E. This is testament to the limitations of the usual $\mathrm{P} / \mathrm{E}$ ratio for predicting returns. We found that a sort statistic based on (EP1+EPM8) gave the best resolution between the value and glamour deciles, ignoring the other six earnings figures, as these two earnings figures have a relatively low correlation. This increased the value premium from $5.98 \%$ to $12.73 \%$.

Finally, we attempted to deal with three possible criticisms. We used rolling five-year data windows to show that the (EP1+EPM8) statistic or something very similar would have been the best statistic over most of the last 29 years, whenever a similar investigation had been performed and whatever retrospective period of data it used. We also showed that although 
the bid-ask spread has a differential effect on the returns of the value and glamour deciles, it could only account for a small proportion of the value premium. We demonstrated that liquidity is only likely to present problems for an institutional investor buying the small company shares concentrated in the value decile. Even so, if the purchases are spread over several days then the price impacts are likely to be modest.

The results presented in this paper suggest several potential avenues for further research. An obvious follow-on would be to determine whether these findings hold true in the much larger US market. We do not doubt that multiple years of earnings will be more useful than one, but it will be interesting to find out whether US earnings from two and three years ago should be negatively weighted and whether the earnings from five to eight years ago are better at predicting returns than the usual $\mathrm{P} / \mathrm{E}$. In the US case, transactions costs and illiquidity are likely to be even less of an issue. Finally, our results suggest the presence of a large and persistent value premium that would be hard to rationalise using standard asset pricing models. It is thus possible that behavioural explanations hold the key. Future research may examine competing psychological models in detail. 


\section{References}

Aggarwal, R., R.P Rao and T. Hiraki (1990), 'Regularities in Tokyo Stock Exchange Security Returns: P/E, Size, and Seasonal Influences', Journal of Financial Research, Vol. 13, pp. 249-63.

Ball, R. (1978), 'Anomalies in Relationships between Securities' Yields and Yield-Surrogates', Journal of Financial Economics, Vol. 6, pp. 103-26.

Ball, R. (1992), 'The Earnings-Price Anomaly' Journal of Accounting and Economics, Vol. 15, Nos. $2 \& 3$, pp. 319-45.

Banz, R.W. and W.J. Breen (1986), 'Sample-Dependent Results Using Accounting and Market Data: Some Evidence' Journal of Finance, Vol. 41, No. 4, pp. 779-93.

Basu, S (1975), 'The Information Content of Price-Earnings Ratios' Financial Management, Vol. 4, No. 2, pp. 53-64.

Basu, S (1977), 'The Investment Performance of Common Stocks in relation to their Price-Earnings Ratios' Journal of Finance, Vol. 32, No. 3, pp. 663-82.

Bird, R. and J. Whitaker (2003), ' The performance of Value and Momentum Investment Portfolios: Recent Experience in the Major European Markets. Journal of Asset Management, Vol. 4, No. 4, pp. 221-46.

Booth, G.G, T. Martikainen, J. Perttunen, and P. Yli-Olli (1994), 'On the Functional Form of Earnings and Stock Prices: International Evidence and Implications for the P/E Anomaly' Journal of Business Finance and Accounting, Vol. 21, No. 3, pp. 395-408.

Brouwer, I., J. van der Put, and C. Veld (1997), 'Contrarian Investment Strategies in a European Context' Journal of Business Finance and Accounting, Vol. 24, Nos. 9\&10, pp. 1353-66.

Cai, J (1997), 'Glamour and Value Strategies on the Tokyo Stock Exchange' Journal of Business Finance and Accounting, Vol. 24, No. 9/10, pp. 1291-310.

Campbell, J.Y. and R.J. Shiller (1988), 'Stock Prices, Earnings, and Expected Dividends' Journal of Finance, Vol. 43, No. 3, pp. 661-76.

Chan, L.C.K., Y. Hamao, and J. Lakonishok (1991), 'Fundamentals and Stock Returns in Japan' Journal of Finance, Vol. 46, No. 5, pp. 1739-64.

Chin, J.Y.F., A.K. Prevost and A.A. Gottesman (2002), 'Contrarian Investing in a Small Capitalization Market: Evidence from New Zealand’ Financial Review, Vol. 37, No. 3, pp. 421-46.

Chou, S.-R. and K.H. Johnson (1990), 'An Empirical Analysis of Stock Market Anomalies: Evidence from the Republic of China in Taiwan', in S.G. Rhee and R.P. Chang (eds.), Pacific-Basin Capital Markets Research (North-Holland: Elsevier Science Publishers).

De Bondt, W.F.M. and R. Thaler (1985), 'Does the Stock Market Overreact?' Journal of Finance, Vol. 40, No. 3, pp. 793-805.

Doeswijk, R.Q (1997), 'Contrarian Investment in the Dutch Stock Market' De Economist, Vol. 145, No. 4, pp. 573-98. 
Dreman, D.N (1998), Contrarian Investment Strategies: The Next Generation (New York: Simon and Schuster).

Fama, E.F. and K.R. French (1992), 'The Cross-Section of Expected Stock Returns' Journal of Finance, Vol. 47, No. 2, pp. 427-65.

Fama, E.F. and K.R. French (1993), 'Common Risk Factors in the Returns on Stocks and Bonds' Journal of Financial Economics, Vol. 33, No. 1, pp. 3-56.

Fama, E.F. and K.R. French (1996), 'Multifactor Explanations of Asset Pricing Anomalies' Journal of Finance, Vol. 51, No. 1, pp. 55-84.

Fama, E.F. and French, K.R (1998), 'Value versus Growth: The International Evidence' Journal of Finance, Vol. 53, No. 6, pp. 1975-99.

Fuller, R.J., L.C. Huberts and M.J. Levinson (1993), 'Returns to E/P Strategies, Higgeldy Piggeldy Growth, Analysts' Forecast Errors, and Omitted Risk Factors' Journal of Portfolio Management Winter, pp. 13-24.

Graham, B. and D. Dodd (1934), Security Analysis (New York: McGraw-Hill).

Gregory, A., R.D.F. Harris and M. Michou (2001), 'An Analysis of Contrarian Investment Strategies in the UK' Journal of Business Finance and Accounting, Vol. 28, No. 9/10, pp. 1193-228.

Jaffe, J., D.B. Keim and R. Westerfield (1989), 'Earnings Yields, Market Values, and Stock Returns' Journal of Finance, Vol. 44, No. 1, pp. 135-48.

Jegadeesh, N. and S. Titman (1993), 'Returns to Buying Winners and Selling Losers: Implications for Stock Market Efficiency’ Journal of Finance, Vol. 48, No. 1, pp. 65-91.

Lakonishok, J., A. Schleifer and R. Vishny (1994), 'Contrarian Investment, Extrapolation, and Risk' Journal of Finance, Vol. 49, No. 5, pp. 1541-78.

Levis, M (1989), ‘ Stock Market Anomalies’ Journal of Banking and Finance, Vol. 13, pp. 675-96.

Levis, M. and M. Liodakis (2001), 'Contrarian Strategies and Investor Expectations: The U.K. Evidence’ Financial Analysts Journal, Vol. 57, No. 5, pp. 43-46.

Nicholson, S.F (1960), 'Price-Earnings Ratios’ Financial Analysts Journal, Vol. 16, No. 4, pp. 43-45.

Nicholson, S.F (1968), 'Price-Earnings Ratios in relation to Investment Results' Financial Analysts Journal, Vol. 24, No. 1, pp. 105-09.

Park, Y.S. and J-J. Lee, (2003), 'An empirical study on the relevance of applying relative valuation models to investment strategies in the Japanese stock market' Japan and the World Economy, Vol. 15, pp. 331-39.

Shiller, R.J. (2000), Irrational Exuberance (Princeton: Princeton University Press). 
Table 1: One-year average returns for decile portfolios, 1975-2003.

Panel A: Using all available data

\begin{tabular}{|l|c|c|c|c|c|c|c|c|}
\hline & EP1 & EP2 & EP3 & EP4 & EP5 & EP6 & EP7 & EP8 \\
\hline Highest P/E & $18.28 \%$ & $18.20 \%$ & $18.62 \%$ & $16.65 \%$ & $17.84 \%$ & $17.83 \%$ & $18.15 \%$ & $16.26 \%$ \\
\hline Decile 2 & $19.25 \%$ & $19.36 \%$ & $16.41 \%$ & $17.98 \%$ & $16.94 \%$ & $17.42 \%$ & $16.16 \%$ & $16.71 \%$ \\
\hline Decile 3 & $18.38 \%$ & $17.32 \%$ & $18.92 \%$ & $18.68 \%$ & $17.78 \%$ & $17.51 \%$ & $17.05 \%$ & $16.43 \%$ \\
\hline Decile 4 & $16.44 \%$ & $18.96 \%$ & $19.45 \%$ & $18.42 \%$ & $19.49 \%$ & $17.81 \%$ & $18.61 \%$ & $18.42 \%$ \\
\hline Decile 5 & $17.96 \%$ & $18.06 \%$ & $17.73 \%$ & $18.58 \%$ & $17.62 \%$ & $19.11 \%$ & $18.34 \%$ & $19.54 \%$ \\
\hline Decile 6 & $18.53 \%$ & $18.73 \%$ & $19.32 \%$ & $18.98 \%$ & $19.97 \%$ & $19.69 \%$ & $19.81 \%$ & $19.81 \%$ \\
\hline Decile 7 & $21.59 \%$ & $19.53 \%$ & $19.86 \%$ & $20.77 \%$ & $19.61 \%$ & $20.18 \%$ & $19.86 \%$ & $19.39 \%$ \\
\hline Decile 8 & $20.86 \%$ & $20.55 \%$ & $21.33 \%$ & $22.11 \%$ & $21.81 \%$ & $20.42 \%$ & $20.58 \%$ & $21.11 \%$ \\
\hline Decile 9 & $22.47 \%$ & $21.75 \%$ & $22.00 \%$ & $22.08 \%$ & $22.48 \%$ & $22.88 \%$ & $22.48 \%$ & $23.05 \%$ \\
\hline Lowest P/E & $24.26 \%$ & $22.82 \%$ & $21.89 \%$ & $22.18 \%$ & $24.27 \%$ & $25.51 \%$ & $27.57 \%$ & $27.87 \%$ \\
\hline \hline D10- D1 & $5.98 \%$ & $4.62 \%$ & $3.28 \%$ & $5.52 \%$ & $6.44 \%$ & $7.67 \%$ & $9.42 \%$ & $11.62 \%$ \\
\hline
\end{tabular}

Panel B: Using only companies that have a full eight years of positive earnings

\begin{tabular}{|l|c|c|c|c|c|c|c|c|}
\hline & EP1 & EP2 & EP3 & EP4 & EP5 & EP6 & EP7 & EP8 \\
\hline Highest P/E & $18.03 \%$ & $18.52 \%$ & $19.31 \%$ & $17.96 \%$ & $17.72 \%$ & $16.79 \%$ & $17.20 \%$ & $16.26 \%$ \\
\hline Decile 2 & $19.18 \%$ & $17.42 \%$ & $16.06 \%$ & $16.49 \%$ & $15.70 \%$ & $15.86 \%$ & $15.96 \%$ & $16.71 \%$ \\
\hline Decile 3 & $18.05 \%$ & $18.60 \%$ & $18.20 \%$ & $18.96 \%$ & $17.72 \%$ & $17.75 \%$ & $17.29 \%$ & $16.43 \%$ \\
\hline Decile 4 & $15.26 \%$ & $17.25 \%$ & $18.23 \%$ & $17.58 \%$ & $17.96 \%$ & $18.17 \%$ & $18.25 \%$ & $18.42 \%$ \\
\hline Decile 5 & $19.56 \%$ & $19.16 \%$ & $18.64 \%$ & $18.53 \%$ & $18.48 \%$ & $19.42 \%$ & $18.10 \%$ & $19.54 \%$ \\
\hline Decile 6 & $18.01 \%$ & $19.51 \%$ & $19.35 \%$ & $18.91 \%$ & $19.73 \%$ & $20.03 \%$ & $20.19 \%$ & $19.81 \%$ \\
\hline Decile 7 & $19.72 \%$ & $19.78 \%$ & $20.53 \%$ & $20.59 \%$ & $20.12 \%$ & $19.95 \%$ & $19.91 \%$ & $19.39 \%$ \\
\hline Decile 8 & $20.28 \%$ & $21.33 \%$ & $20.81 \%$ & $21.03 \%$ & $21.27 \%$ & $19.77 \%$ & $21.10 \%$ & $21.11 \%$ \\
\hline Decile 9 & $24.11 \%$ & $21.07 \%$ & $21.48 \%$ & $22.64 \%$ & $23.59 \%$ & $23.70 \%$ & $23.16 \%$ & $23.05 \%$ \\
\hline Lowest P/E & $26.34 \%$ & $25.93 \%$ & $25.94 \%$ & $25.92 \%$ & $26.28 \%$ & $27.14 \%$ & $27.44 \%$ & $27.87 \%$ \\
\hline D10- D1 & $8.31 \%$ & $7.41 \%$ & $6.63 \%$ & $7.96 \%$ & $8.56 \%$ & $10.35 \%$ & $10.24 \%$ & $11.62 \%$ \\
\hline
\end{tabular}

Note: Companies are assigned to portfolios using statistics EP1 (the inverse of the usual P/E ratio) through to EP8 (the sum of normalised earnings over the last eight years, divided by the current share price).

Table 2: Average returns for each decile for holding periods of 1 to 8 years

\begin{tabular}{|l|r|r|r|r|r|r|r|r|}
\hline & 1 Year & 2 Years & 3 Years & 4 Years & 5 Years & 6 Years & 7 Years & 8 Years \\
\hline Highest P/E & $16.26 \%$ & $14.43 \%$ & $13.87 \%$ & $13.80 \%$ & $13.23 \%$ & $13.48 \%$ & $13.51 \%$ & $13.20 \%$ \\
\hline Decile 2 & $16.71 \%$ & $14.01 \%$ & $13.58 \%$ & $13.48 \%$ & $13.77 \%$ & $13.87 \%$ & $14.05 \%$ & $14.13 \%$ \\
\hline Decile 3 & $16.43 \%$ & $14.85 \%$ & $15.35 \%$ & $15.27 \%$ & $15.41 \%$ & $15.33 \%$ & $15.16 \%$ & $14.98 \%$ \\
\hline Decile 4 & $18.42 \%$ & $17.34 \%$ & $17.46 \%$ & $16.96 \%$ & $16.15 \%$ & $15.87 \%$ & $15.46 \%$ & $15.64 \%$ \\
\hline Decile 5 & $19.54 \%$ & $17.37 \%$ & $16.64 \%$ & $16.24 \%$ & $15.83 \%$ & $15.77 \%$ & $15.79 \%$ & $15.74 \%$ \\
\hline Decile 6 & $19.81 \%$ & $18.37 \%$ & $17.92 \%$ & $17.50 \%$ & $17.13 \%$ & $16.87 \%$ & $16.03 \%$ & $15.98 \%$ \\
\hline Decile 7 & $19.39 \%$ & $18.85 \%$ & $18.01 \%$ & $17.69 \%$ & $16.97 \%$ & $16.85 \%$ & $16.83 \%$ & $16.80 \%$ \\
\hline Decile 8 & $21.11 \%$ & $19.92 \%$ & $20.12 \%$ & $19.11 \%$ & $18.28 \%$ & $17.73 \%$ & $17.49 \%$ & $16.87 \%$ \\
\hline Decile 9 & $23.05 \%$ & $22.26 \%$ & $21.47 \%$ & $20.28 \%$ & $18.56 \%$ & $18.19 \%$ & $17.74 \%$ & $17.39 \%$ \\
\hline Lowest P/E & $27.87 \%$ & $26.13 \%$ & $25.31 \%$ & $24.08 \%$ & $22.23 \%$ & $21.31 \%$ & $20.98 \%$ & $20.99 \%$ \\
\hline D10- D1 & $11.62 \%$ & $11.70 \%$ & $11.44 \%$ & $10.28 \%$ & $9.01 \%$ & $7.83 \%$ & $7.47 \%$ & $7.78 \%$ \\
\hline
\end{tabular}

Notes: In this table we employ throughout only firms with a full eight years of earnings history. Companies are assigned to portfolios based on the sum of normalised earnings over the previous eight years. The one-year returns are repeated from the EP8 column of Table 1 Panel B. 
Table 3: $t$-test $p$-values comparing EPn returns to EP1 returns, for $n=2, \ldots, 8$, and for 1-year to 8-year holding periods.

Panel A: Are the value decile returns different for EPn versus EP1?

\begin{tabular}{|c|c|c|c|c|c|c|c|c|}
\hline & 1 Year & 2 Years & 3 Years & 4 Years & 5 Years & 6 Years & 7 Years & 8 Years \\
\hline EP2 & 0.2245 & 0.2282 & 0.5483 & 0.7977 & 0.8593 & 0.4935 & 0.4271 & $0.0492^{*}$ \\
\hline EP3 & 0.0879 & 0.3665 & 0.8460 & 0.7465 & 0.5853 & 0.2831 & 0.2521 & 0.1862 \\
\hline EP4 & 0.1412 & 0.6869 & 0.5277 & 0.2430 & 0.1550 & 0.0736 & 0.0650 & 0.0532 \\
\hline EP5 & 0.9911 & 0.2964 & 0.1765 & 0.0634 & 0.0605 & $0.0447^{*}$ & 0.0876 & 0.0619 \\
\hline EP6 & 0.4330 & $0.0482^{*}$ & $0.0184^{*}$ & $0.0095^{* *}$ & $0.0077^{* *}$ & $0.0142^{*}$ & $0.0353^{*}$ & $0.0237^{*}$ \\
\hline EP7 & 0.0629 & $0.0196^{*}$ & $0.0176^{*}$ & $0.0098^{* *}$ & $0.0322^{*}$ & $0.0419^{*}$ & $0.0402^{*}$ & $0.0129^{*}$ \\
\hline EP8 & 0.0864 & $0.0338^{*}$ & $0.0100^{*}$ & $0.0095^{* *}$ & $0.0087^{* *}$ & $0.0045^{* *}$ & $0.0073^{* *}$ & $0.0024^{* *}$ \\
\hline
\end{tabular}

Panel B: Are the D10-D1 value premia different for EPn versus EP1?

\begin{tabular}{|c|c|c|c|c|c|c|c|c|}
\hline & 1 Year & 2 Years & 3 Years & 4 Years & 5 Years & 6 Years & 7 Years & 8 Years \\
\hline EP2 & 0.6300 & 0.6357 & 0.8589 & 0.9239 & 0.4756 & 0.2002 & 0.2060 & 0.0228 \\
\hline EP3 & 0.4172 & 0.9070 & 0.4665 & 0.6206 & 0.4652 & 0.4654 & 0.6144 & 0.1333 \\
\hline EP4 & 0.8860 & 0.7017 & 0.2874 & 0.2916 & 0.1554 & 0.2260 & 0.2387 & 0.0754 \\
\hline EP5 & 0.8905 & 0.3866 & 0.2154 & 0.1808 & 0.0878 & 0.1322 & 0.1017 & $0.0402^{*}$ \\
\hline EP6 & 0.6261 & 0.1592 & $0.0462^{*}$ & $0.0430^{*}$ & $0.0202^{*}$ & $0.0472^{*}$ & $0.0219^{*}$ & $0.0036^{* *}$ \\
\hline EP7 & 0.3907 & 0.1318 & 0.0768 & 0.0626 & $0.0370^{*}$ & 0.1183 & $0.0337^{*}$ & $0.0022^{* *}$ \\
\hline EP8 & 0.1450 & 0.0678 & $0.0294^{*}$ & $0.0417^{*}$ & $0.0138^{*}$ & $0.0282^{*}$ & $0.0070^{* *}$ & $0.0002^{* * *}$ \\
\hline
\end{tabular}

Note: We match returns by year, decile and returns period, so that the only factor that varies is the number of years of past earnings taken into account. We then perform a paired sample, two-tailed t-test; *, ** and $* * *$ denote significance at the $5 \%, 1 \%$ and $0.1 \%$ levels respectively.

Table 4: Average one-year returns after assigning companies to decile portfolios using individual past years of earnings EP1 through to EPM8

\begin{tabular}{|l|c|c|c|c|c|c|c|c|}
\hline & $\begin{array}{c}\text { EP1 } \\
\text { alone }\end{array}$ & $\begin{array}{c}\text { EPM2 } \\
\text { alone }\end{array}$ & $\begin{array}{c}\text { EPM3 } \\
\text { alone }\end{array}$ & $\begin{array}{c}\text { EPM4 } \\
\text { alone }\end{array}$ & $\begin{array}{c}\text { EPM5 } \\
\text { alone }\end{array}$ & $\begin{array}{c}\text { EPM6 } \\
\text { alone }\end{array}$ & $\begin{array}{c}\text { EPM7 } \\
\text { alone }\end{array}$ & $\begin{array}{c}\text { EPM8 } \\
\text { alone }\end{array}$ \\
\hline High P/E & $18.03 \%$ & $20.66 \%$ & $19.72 \%$ & $18.47 \%$ & $16.14 \%$ & $16.46 \%$ & $16.39 \%$ & $16.24 \%$ \\
\hline Decile 2 & $19.18 \%$ & $18.06 \%$ & $16.88 \%$ & $16.61 \%$ & $16.52 \%$ & $17.10 \%$ & $16.64 \%$ & $17.05 \%$ \\
\hline Decile 3 & $18.05 \%$ & $19.11 \%$ & $18.78 \%$ & $17.41 \%$ & $16.15 \%$ & $17.66 \%$ & $18.01 \%$ & $16.50 \%$ \\
\hline Decile 4 & $15.26 \%$ & $19.31 \%$ & $18.87 \%$ & $18.23 \%$ & $18.64 \%$ & $16.30 \%$ & $16.05 \%$ & $18.32 \%$ \\
\hline Decile 5 & $19.56 \%$ & $16.91 \%$ & $18.22 \%$ & $18.23 \%$ & $19.35 \%$ & $18.68 \%$ & $20.65 \%$ & $18.00 \%$ \\
\hline Decile 6 & $18.01 \%$ & $19.19 \%$ & $18.34 \%$ & $19.19 \%$ & $19.55 \%$ & $20.99 \%$ & $19.80 \%$ & $20.44 \%$ \\
\hline Decile 7 & $19.72 \%$ & $19.65 \%$ & $19.96 \%$ & $20.82 \%$ & $20.45 \%$ & $21.13 \%$ & $18.73 \%$ & $19.94 \%$ \\
\hline Decile 8 & $20.28 \%$ & $20.51 \%$ & $18.78 \%$ & $21.67 \%$ & $22.80 \%$ & $20.60 \%$ & $21.39 \%$ & $22.23 \%$ \\
\hline Decile 9 & $24.11 \%$ & $21.31 \%$ & $23.93 \%$ & $21.50 \%$ & $21.87 \%$ & $21.70 \%$ & $23.22 \%$ & $22.43 \%$ \\
\hline Low P/E & $26.34 \%$ & $23.86 \%$ & $25.11 \%$ & $26.46 \%$ & $27.12 \%$ & $27.97 \%$ & $27.69 \%$ & $27.40 \%$ \\
\hline D10 - D1 & $8.31 \%$ & $3.20 \%$ & $5.38 \%$ & $7.99 \%$ & $10.98 \%$ & $11.51 \%$ & $11.30 \%$ & $11.15 \%$ \\
\hline
\end{tabular}

Note: The EP1 returns are repeated from Table 1 Panel B. All UK stocks with eight years of positive earnings are used, 1975-2003. 
Table 5: Average one-year returns after assigning companies to decile portfolios using different EP1-EPM8 weighting rules

\begin{tabular}{|c|c|c|c|c|c|c|}
\hline & 1 & 2 & 3 & 4 & 5 & \multirow{3}{*}{$\begin{array}{c}6 \\
\text { Linear } \\
\text { Regression } \\
\text { Weights }\end{array}$} \\
\hline & \multirow[b]{2}{*}{$\begin{array}{c}\text { Equal } \\
\text { weights }\end{array}$} & \multicolumn{2}{|c|}{ Increasing weights } & \multicolumn{2}{|c|}{ Decreasing weights } & \\
\hline & & Linear & $\begin{array}{l}\text { Inverse } \\
\text { square }\end{array}$ & Linear & $\begin{array}{l}\text { Inverse } \\
\text { square }\end{array}$ & \\
\hline \multicolumn{6}{|c|}{ Weights assigned } & \\
\hline EP1 & 1 & 8 & 1 & 1 & $1 / 64$ & 0.8442 \\
\hline EPM2 & 1 & 7 & $1 / 4$ & 2 & $1 / 49$ & -0.1794 \\
\hline EPM3 & 1 & 6 & $1 / 9$ & 3 & $1 / 36$ & -0.3327 \\
\hline EPM4 & 1 & 5 & $1 / 16$ & 4 & $1 / 25$ & 0.4347 \\
\hline EPM5 & 1 & 4 & $1 / 25$ & 5 & $1 / 16$ & 0.1897 \\
\hline EPM6 & 1 & 3 & $1 / 36$ & 6 & $1 / 9$ & 0.0223 \\
\hline EPM7 & 1 & 2 & $1 / 49$ & 7 & $1 / 4$ & 0.1235 \\
\hline EPM8 & 1 & 1 & $1 / 64$ & 8 & 1 & 0.0499 \\
\hline \multicolumn{6}{|c|}{ One-Year Returns } & \\
\hline High P/E & $16.26 \%$ & $16.89 \%$ & $17.84 \%$ & $15.81 \%$ & $15.19 \%$ & $16.68 \%$ \\
\hline Decile 2 & $16.71 \%$ & $16.30 \%$ & $16.44 \%$ & $16.05 \%$ & $16.79 \%$ & $14.83 \%$ \\
\hline Decile 3 & $16.43 \%$ & $18.10 \%$ & $18.03 \%$ & $16.95 \%$ & $16.52 \%$ & $17.40 \%$ \\
\hline Decile 4 & $18.42 \%$ & $17.24 \%$ & $17.48 \%$ & $18.35 \%$ & $19.05 \%$ & $17.60 \%$ \\
\hline Decile 5 & $19.54 \%$ & $18.93 \%$ & $17.96 \%$ & $19.14 \%$ & $19.00 \%$ & $19.77 \%$ \\
\hline Decile 6 & $19.81 \%$ & $19.66 \%$ & $20.03 \%$ & $20.69 \%$ & $19.42 \%$ & $18.28 \%$ \\
\hline Decile 7 & $19.39 \%$ & $20.11 \%$ & $20.76 \%$ & $19.92 \%$ & $20.80 \%$ & $20.36 \%$ \\
\hline Decile 8 & $21.11 \%$ & $20.79 \%$ & $21.50 \%$ & $20.27 \%$ & $21.00 \%$ & $22.33 \%$ \\
\hline Decile 9 & $23.05 \%$ & $23.83 \%$ & $20.77 \%$ & $23.48 \%$ & $23.84 \%$ & $22.89 \%$ \\
\hline Low P/E & $27.87 \%$ & $26.68 \%$ & $27.75 \%$ & $27.98 \%$ & $27.01 \%$ & $28.45 \%$ \\
\hline D10 - D1 & $11.62 \%$ & $9.79 \%$ & $9.91 \%$ & $12.17 \%$ & $11.82 \%$ & $11.77 \%$ \\
\hline
\end{tabular}

Note: The data are all UK stocks with eight years of positive earnings, 1975-2003. Read each column as a separate calculation of returns over the 29 years, that first shows the weights applied, then the decile portfolio returns resulting from assigning companies to deciles using a $\mathrm{P} / \mathrm{E}$ constructed from those weights. The equallyweighted returns are repeated from Table 1 Panel B. 
Table 6: Average one-year returns after assigning companies to decile portfolios using EP1 plus (EPM2 through to EPM8)

\begin{tabular}{|c|c|c|c|c|c|c|c|}
\hline & $\begin{array}{l}\text { EP1 + } \\
\text { EPM2 }\end{array}$ & $\begin{array}{l}\text { EP1 + } \\
\text { EPM3 }\end{array}$ & $\begin{array}{l}\text { EP1+ } \\
\text { EPM4 }\end{array}$ & $\begin{array}{l}\text { EP1 + } \\
\text { EPM5 }\end{array}$ & $\begin{array}{l}\text { EP1 + } \\
\text { EPM6 }\end{array}$ & $\begin{array}{l}\text { EP1 + } \\
\text { EPM7 }\end{array}$ & $\begin{array}{l}\text { EP1 + } \\
\text { EPM8 }\end{array}$ \\
\hline \multicolumn{8}{|c|}{ Weights assigned } \\
\hline EP1 & 1 & 1 & 1 & 1 & 1 & 1 & 1 \\
\hline EPM2 & 1 & 0 & 0 & 0 & 0 & 0 & 0 \\
\hline EPM3 & 0 & 1 & 0 & 0 & 0 & 0 & 0 \\
\hline EPM4 & 0 & 0 & 1 & 0 & 0 & 0 & 0 \\
\hline EPM5 & 0 & 0 & 0 & 1 & 0 & 0 & 0 \\
\hline EPM6 & 0 & 0 & 0 & 0 & 1 & 0 & 0 \\
\hline EPM7 & 0 & 0 & 0 & 0 & 0 & 1 & 0 \\
\hline EPM8 & 0 & 0 & 0 & 0 & 0 & 0 & 1 \\
\hline \multicolumn{8}{|c|}{ One-Year Returns } \\
\hline High P/E & $18.52 \%$ & $18.32 \%$ & $17.32 \%$ & $17.11 \%$ & $16.76 \%$ & $16.71 \%$ & $16.21 \%$ \\
\hline Decile 2 & $17.42 \%$ & $16.73 \%$ & $16.37 \%$ & $15.68 \%$ & $16.86 \%$ & $16.82 \%$ & $16.15 \%$ \\
\hline Decile 3 & $18.60 \%$ & $17.67 \%$ & $16.79 \%$ & $15.69 \%$ & $15.68 \%$ & $15.71 \%$ & $17.27 \%$ \\
\hline Decile 4 & $17.25 \%$ & $17.93 \%$ & $17.68 \%$ & $18.49 \%$ & $17.47 \%$ & $17.58 \%$ & $16.55 \%$ \\
\hline Decile 5 & $19.16 \%$ & $18.18 \%$ & $17.49 \%$ & $18.59 \%$ & $18.74 \%$ & $18.73 \%$ & $20.03 \%$ \\
\hline Decile 6 & $19.51 \%$ & $19.36 \%$ & $20.36 \%$ & $19.98 \%$ & $19.49 \%$ & $19.44 \%$ & $18.13 \%$ \\
\hline Decile 7 & $19.78 \%$ & $20.38 \%$ & $21.41 \%$ & $20.78 \%$ & $21.12 \%$ & $19.18 \%$ & $20.06 \%$ \\
\hline Decile 8 & $21.33 \%$ & $21.92 \%$ & $22.53 \%$ & $21.30 \%$ & $20.81 \%$ & $23.90 \%$ & $23.34 \%$ \\
\hline Decile 9 & $21.07 \%$ & $21.54 \%$ & $21.69 \%$ & $22.49 \%$ & $23.43 \%$ & $22.69 \%$ & $21.92 \%$ \\
\hline Low P/E & $25.93 \%$ & $26.51 \%$ & $26.95 \%$ & $28.46 \%$ & $28.25 \%$ & $27.82 \%$ & $28.95 \%$ \\
\hline D10 - D1 & $7.41 \%$ & $8.19 \%$ & $9.63 \%$ & $11.36 \%$ & $11.49 \%$ & $11.12 \%$ & $12.73 \%$ \\
\hline
\end{tabular}

Note: All UK stocks with eight years of positive earnings are used, 1975-2003.

Table 7: Correlations between the eight individual past years of earnings

\begin{tabular}{|l|c|c|c|c|c|c|c|}
\hline & EPM7 & EPM6 & EPM5 & EPM4 & EPM3 & EPM2 & EP1 \\
\hline EPM8 & 0.8267 & 0.6984 & 0.6320 & 0.5415 & 0.4762 & 0.3779 & 0.2765 \\
\hline EPM7 & & 0.8180 & 0.7258 & 0.6095 & 0.5324 & 0.4263 & 0.2959 \\
\hline EPM6 & & & 0.8023 & 0.6553 & 0.5493 & 0.4209 & 0.3012 \\
\hline EPM5 & & & & 0.8180 & 0.6602 & 0.5137 & 0.3431 \\
\hline EPM4 & & & & & 0.7954 & 0.6100 & 0.3891 \\
\hline EPM3 & & & & & & 0.7317 & 0.4702 \\
\hline EPM2 & & & & & & & 0.6136 \\
\hline
\end{tabular}

Note: All UK stocks with eight years of positive earnings are used, 1975-2003. 
Table 8: Summary statistics from calculating individual year resolutions for various weighting rules, 1975-2003

\begin{tabular}{|c|c|c|c|c|c|c|}
\hline & $\begin{array}{c}\text { Equal } \\
\text { weights }\end{array}$ & $\begin{array}{c}\text { Linear } \\
\text { Regression }\end{array}$ & $\begin{array}{c}\text { Linear } \\
\text { descending } \\
\text { weights, } \\
\text { EPM8 largest }\end{array}$ & $\begin{array}{c}\text { Linear } \\
\text { ascending } \\
\text { weights, EP1 } \\
\text { largest }\end{array}$ & EP1+EPM8 & $\begin{array}{c}\text { EP1 } \\
\text { +EPM4 } \\
\text { +EPM8 }\end{array}$ \\
\hline $\begin{array}{c}\text { Average } \\
\text { resolution }\end{array}$ & $11.62 \%$ & $11.77 \%$ & $12.15 \%$ & $9.79 \%$ & $12.73 \%$ & $13.13 \%$ \\
\hline $\begin{array}{c}\text { Standard } \\
\text { deviation }\end{array}$ & $21.01 \%$ & $17.31 \%$ & $20.49 \%$ & $21.13 \%$ & $20.17 \%$ & $21.08 \%$ \\
\hline $\begin{array}{c}\text { Number of } \\
\text { years that } \\
\text { rule is best }\end{array}$ & 3 & 6 & 5 & 1 & 10 & 4 \\
\hline
\end{tabular}

Note: The 'best in $\mathrm{n}$ years' figure is based on calculating the difference between the glamour and value deciles for each year individually from 1975 to 2003 for each weighting rule. It shows the number of years in which that rule gave the highest resolution.

Table 9: Average bid-ask spread costs on one-year returns, grouping by market value category, 1987-2003

\begin{tabular}{|l|c|c|c|c|c|c|c|c|c|c|}
\hline MV Category & $\mathbf{1}$ & $\mathbf{2}$ & $\mathbf{3}$ & $\mathbf{4}$ & $\mathbf{5}$ & $\mathbf{6}$ & $\mathbf{7}$ & $\mathbf{8}$ & $\mathbf{9}$ & $\mathbf{1 0}$ \\
\hline Total spread & $8.20 \%$ & $6.92 \%$ & $5.72 \%$ & $4.62 \%$ & $4.42 \%$ & $4.32 \%$ & $3.59 \%$ & $3.42 \%$ & $3.04 \%$ & $2.65 \%$ \\
\hline \multicolumn{10}{|l|}{$\mid$} \\
\hline MV Category & $\mathbf{1 1}$ & $\mathbf{1 2}$ & $\mathbf{1 3}$ & $\mathbf{1 4}$ & $\mathbf{1 5}$ & $\mathbf{1 6}$ & $\mathbf{1 7}$ & $\mathbf{1 8}$ & $\mathbf{1 9}$ & $\mathbf{2 0}$ \\
\hline Total spread & $2.42 \%$ & $2.37 \%$ & $2.24 \%$ & $1.93 \%$ & $1.72 \%$ & $1.60 \%$ & $1.58 \%$ & $1.53 \%$ & $1.32 \%$ & $0.95 \%$ \\
\hline
\end{tabular}

Note: Bid and ask prices are only available from Datastream starting in 1987.

Table 10: Compound annual returns, average market value category (1-20) and average market betas for 'EP1+EPM8' with and without the effect of the bid-ask spread on

returns.

\begin{tabular}{|l|c|c|c|c|}
\hline & Return & $\begin{array}{c}\text { Return net } \\
\text { of spread }\end{array}$ & $\begin{array}{c}\text { MV } \\
\text { Category }\end{array}$ & Beta \\
\hline High P/E & $16.21 \%$ & $14.64 \%$ & 11.65 & 1.0232 \\
\hline Decile 2 & $16.15 \%$ & $13.93 \%$ & 12.64 & 0.9594 \\
\hline Decile 3 & $17.27 \%$ & $14.78 \%$ & 12.72 & 0.9905 \\
\hline Decile 4 & $16.55 \%$ & $13.99 \%$ & 12.16 & 0.9589 \\
\hline Decile 5 & $20.03 \%$ & $17.26 \%$ & 11.69 & 0.9440 \\
\hline Decile 6 & $18.13 \%$ & $15.12 \%$ & 11.03 & 0.9266 \\
\hline Decile 7 & $20.06 \%$ & $16.67 \%$ & 10.04 & 0.9577 \\
\hline Decile 8 & $23.34 \%$ & $19.59 \%$ & 9.20 & 0.9123 \\
\hline Decile 9 & $21.92 \%$ & $18.08 \%$ & 7.91 & 0.9277 \\
\hline Low P/E & $28.95 \%$ & $24.77 \%$ & 6.01 & 0.9998 \\
\hline D10 - D1 & $12.73 \%$ & $10.13 \%$ & - & - \\
\hline
\end{tabular}


Table 11: Returns for extreme deciles of portfolios sorted by EP1, EP8, book value-toprice and market capitalisation, over holding periods of 1 to 8 years

\begin{tabular}{|c|c|c|c|c|c|c|c|c|c|}
\hline Sort by & Po & $\begin{array}{c}1 \\
\text { Year }\end{array}$ & $\begin{array}{c}2 \\
\text { Years } \\
\end{array}$ & $\begin{array}{c}3 \\
\text { Years } \\
\end{array}$ & $\begin{array}{c}4 \\
\text { Years } \\
\end{array}$ & $\begin{array}{c}5 \\
\text { Years } \\
\end{array}$ & $\begin{array}{c}6 \\
\text { Years } \\
\end{array}$ & $\begin{array}{c}7 \\
\text { Years } \\
\end{array}$ & $\begin{array}{c}8 \\
\text { Years } \\
\end{array}$ \\
\hline \multirow{3}{*}{ EF } & 1 & $13.65 \%$ & $16.28 \%$ & $13.85 \%$ & $13.91 \%$ & $13.00 \%$ & $13.17 \%$ & $13.09 \%$ & $13.28 \%$ \\
\hline & & $0.85 \%$ & $22.81 \%$ & $21.83 \%$ & $20.16 \%$ & $19.01 \%$ & $17.53 \%$ & $16.93 \%$ & $16.64 \%$ \\
\hline & & $21 \%$ & $6.52 \%$ & $7.98 \%$ & $6.25 \%$ & $6.01 \%$ & $4.36 \%$ & $3.84 \%$ & $3.36 \%$ \\
\hline \multirow[b]{3}{*}{ EP8 } & & & & & & & & & \\
\hline & & & & & & & & & \\
\hline & & $54 \%$ & $20 \%$ & $12.61 \%$ & $11.82 \%$ & $10.97 \%$ & $8.62 \%$ & $8.13 \%$ & $7.25 \%$ \\
\hline & & & & & & & & & \\
\hline \multirow{3}{*}{$\begin{array}{c}\text { Book } \\
\text { value- } \\
\text { to-price }\end{array}$} & & $.47 \%$ & $5.50 \%$ & $4.00 \%$ & $2.93 \%$ & $12.67 \%$ & $12.74 \%$ & $12.46 \%$ & $12.53 \%$ \\
\hline & & $22.82 \%$ & $5.09 \%$ & $23.45 \%$ & $22.23 \%$ & $20.98 \%$ & $18.90 \%$ & $17.98 \%$ & $17.47 \%$ \\
\hline & & $8.35 \%$ & $8.59 \%$ & $9.45 \%$ & $9.30 \%$ & $8.31 \%$ & $6.16 \%$ & $5.52 \%$ & $4.94 \%$ \\
\hline \multirow{3}{*}{$\begin{array}{l}\text { Market } \\
\text { capital- } \\
\text { isation }\end{array}$} & & & & $87 \%$ & $89 \%$ & $2 \%$ & $2.45 \%$ & $2.53 \%$ & $12.58 \%$ \\
\hline & & $22.69 \%$ & $25.30 \%$ & $24.00 \%$ & $21.84 \%$ & $19.81 \%$ & $17.74 \%$ & $16.74 \%$ & $16.41 \%$ \\
\hline & D10 - D1 & $11.78 \%$ & $13.16 \%$ & $12.12 \%$ & $9.95 \%$ & $7.69 \%$ & $5.29 \%$ & $4.21 \%$ & $3.83 \%$ \\
\hline
\end{tabular}

Table 12: Median number of days of turnover represented by each trade, for a private investor with $£ 50,000$ in 2003 and for a hedge fund with $£ 20 \mathrm{~m}$. EP1 and EP8 are used to assign companies to deciles.

\begin{tabular}{|c|c|c||c|c|}
\hline & \multicolumn{2}{|c|}{ EP1 } & \multicolumn{2}{c|}{ EP8 } \\
\hline Decile & $\begin{array}{c}\text { Days of turnover } \\
\text { for private investor }\end{array}$ & $\begin{array}{c}\text { Days of turnover } \\
\text { for hedge fund }\end{array}$ & $\begin{array}{c}\text { Days of turnover } \\
\text { for private investor }\end{array}$ & $\begin{array}{c}\text { Days of turnover } \\
\text { for hedge fund }\end{array}$ \\
\hline High P/E & 0.0023 & 0.93 & 0.0005 & 0.20 \\
\hline $\mathbf{2}$ & 0.0009 & 0.38 & 0.0005 & 0.18 \\
\hline $\mathbf{3}$ & 0.0013 & 0.51 & 0.0004 & 0.17 \\
\hline $\mathbf{4}$ & 0.0008 & 0.30 & 0.0004 & 0.15 \\
\hline $\mathbf{5}$ & 0.0008 & 0.32 & 0.0007 & 0.26 \\
\hline $\mathbf{6}$ & 0.0011 & 0.42 & 0.0008 & 0.31 \\
\hline $\mathbf{7}$ & 0.0015 & 0.62 & 0.0008 & 0.33 \\
\hline $\mathbf{8}$ & 0.0021 & 0.84 & 0.0022 & 0.89 \\
\hline $\mathbf{9}$ & 0.0035 & 1.41 & 0.0058 & 2.30 \\
\hline Low P/E & 0.0084 & 3.37 & 0.0114 & 4.54 \\
\hline
\end{tabular}

Table 13: Portfolio values and percentage returns for glamour and value deciles using EP1 and (EP1+EPM8) to assign companies to deciles, 1975-2003

\begin{tabular}{|c||c|c||c|c|}
\hline \multicolumn{1}{|c||}{} & \multicolumn{2}{c||}{ EP1+EPM8 } & \multicolumn{2}{c|}{ EP1 (traditional EP) } \\
\cline { 2 - 5 } & Value Decile & Glamour Decile & Value Decile & Glamour Decile \\
\hline Value in 1975 & $£ 1,000$ & $£ 1,000$ & $£ 1,000$ & $£ 1,000$ \\
\hline Value in 2004 & $£ 952,028$ & $£ 44,539$ & $£ 548,274$ & $£ 70,350$ \\
\hline $\begin{array}{c}\text { Compound } \\
\text { Return }\end{array}$ & $26.68 \%$ & $13.99 \%$ & $24.29 \%$ & $15.80 \%$ \\
\hline
\end{tabular}


Figure 1: Average annual returns using EP1 and EP8 as rules for assignment of companies to decile portfolios. All UK stocks, 1975-2003

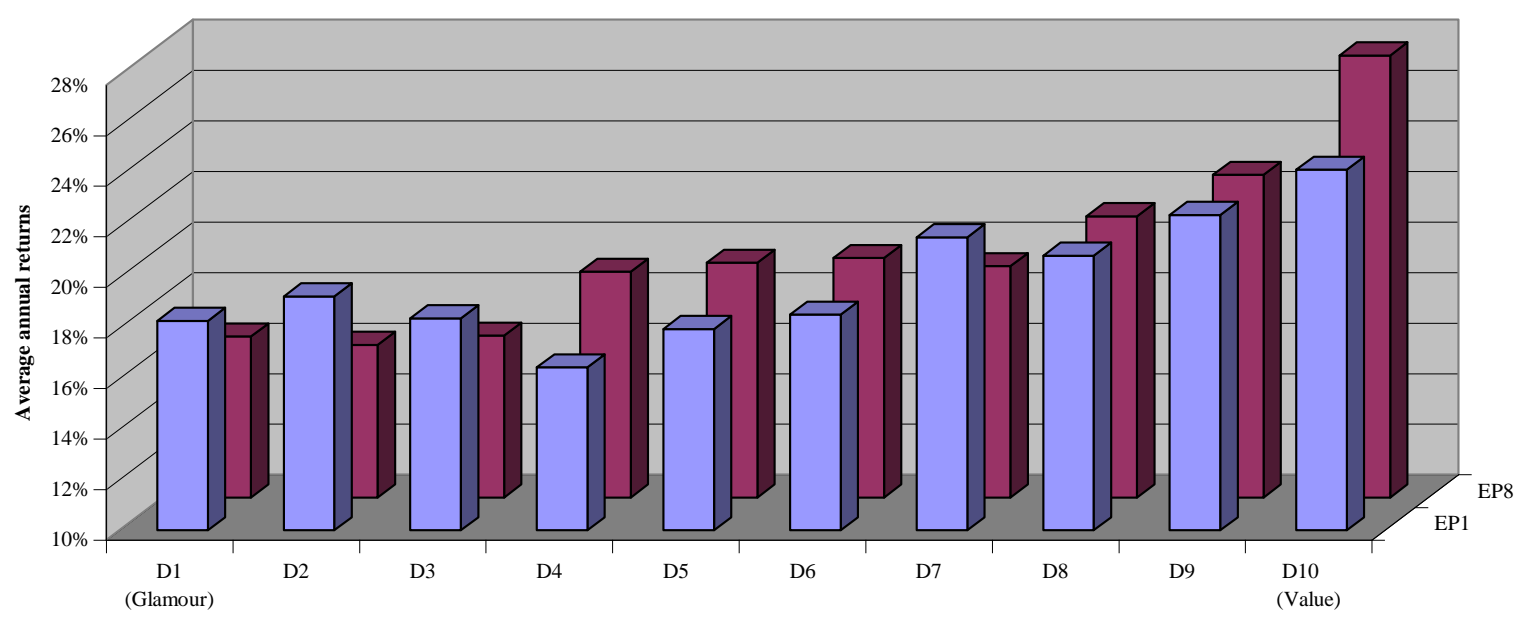

Figure 2: Standard deviation of one-year returns, 1975-2003

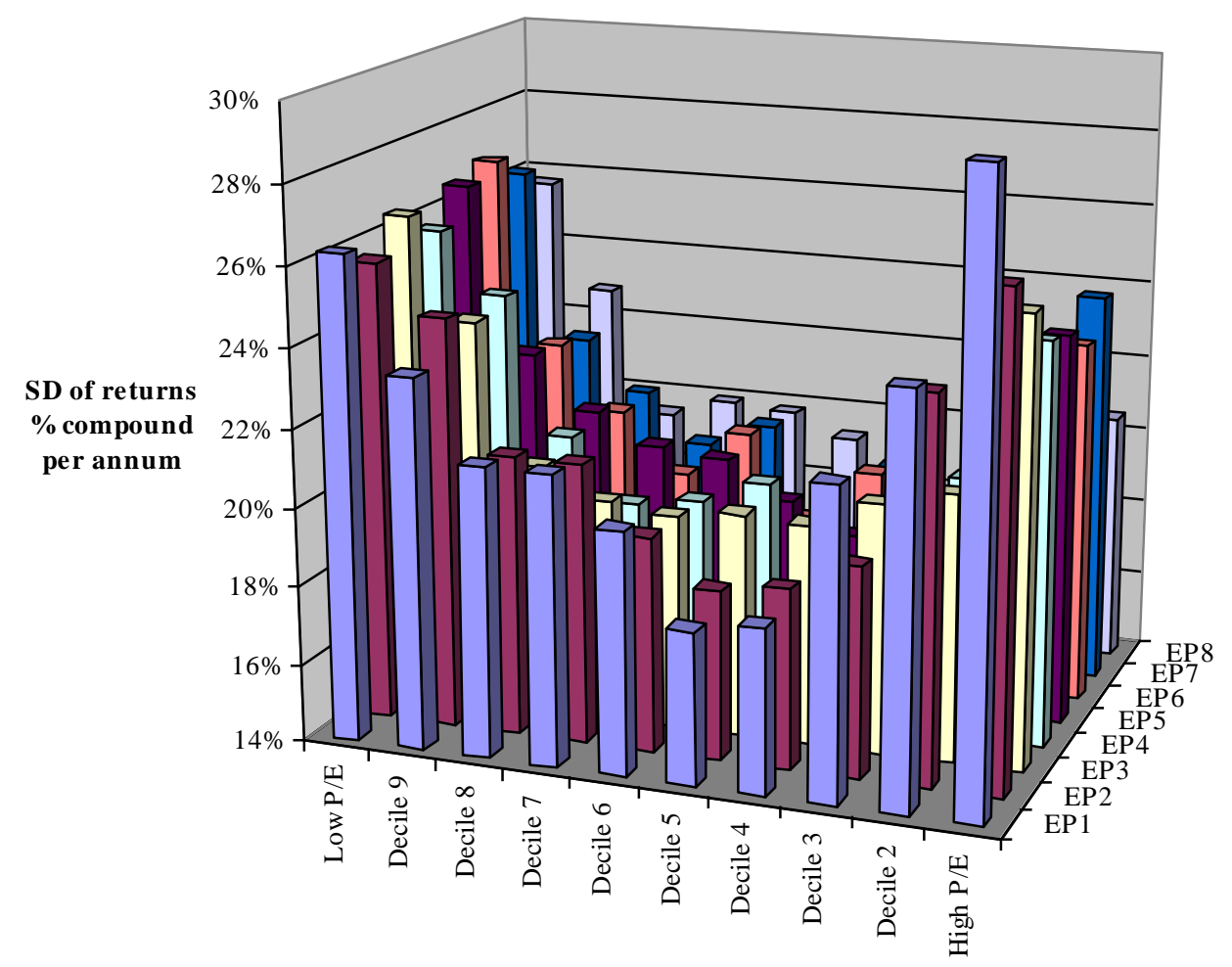


Figure 3: Sharpe ratio of returns for a one-year holding period, 1975-2003

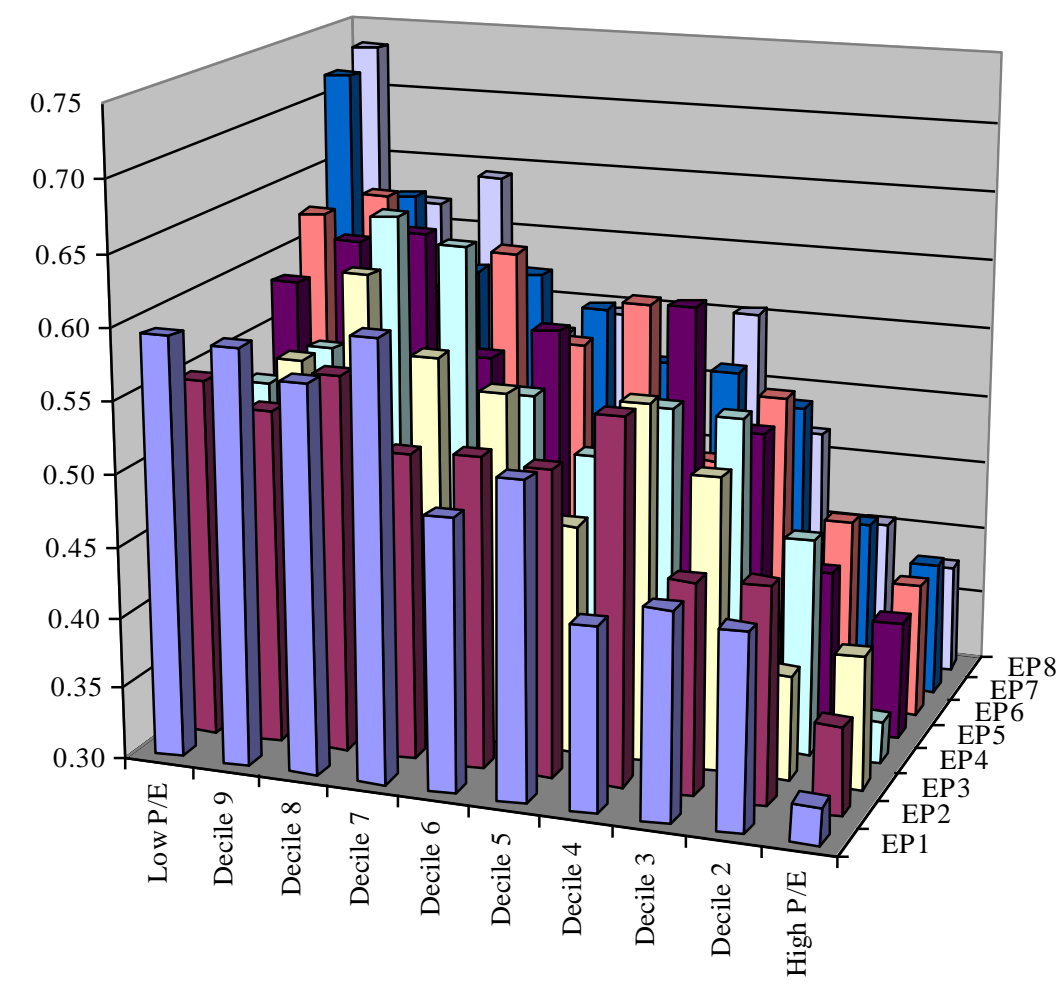

Figure 4: Five-year rolling average resolutions (value premia) for different simple weighting regimes, 1975-2003

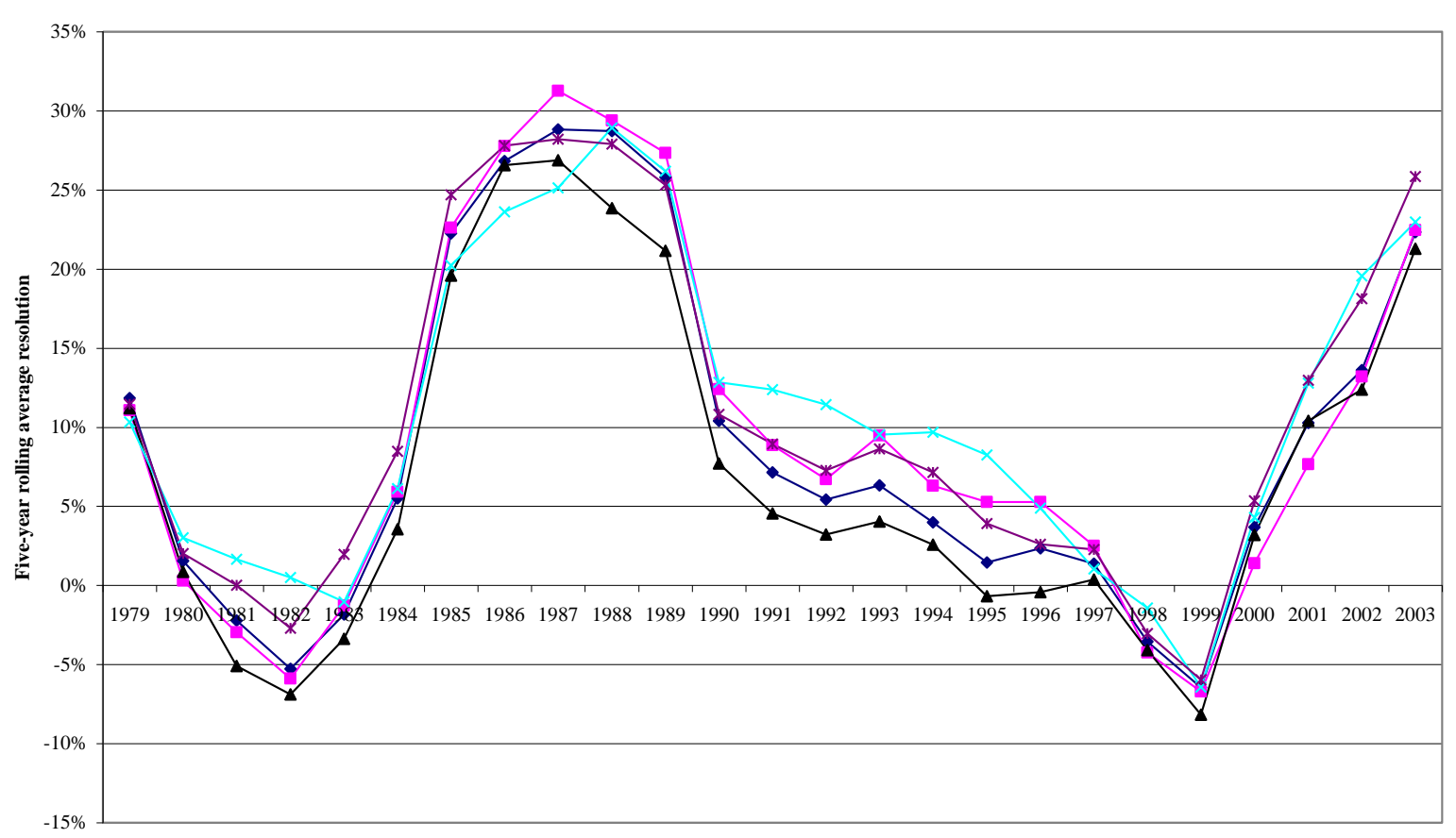

$\bullet$ Equal $\rightarrow$ - Desc $\multimap$ Asc $\rightarrow-$ EP1+EPM8 $\rightarrow$ EP1+4+8 
Figure 5: Average cost of the bid-ask spread to one-year returns grouped by market value category, 1987-2003

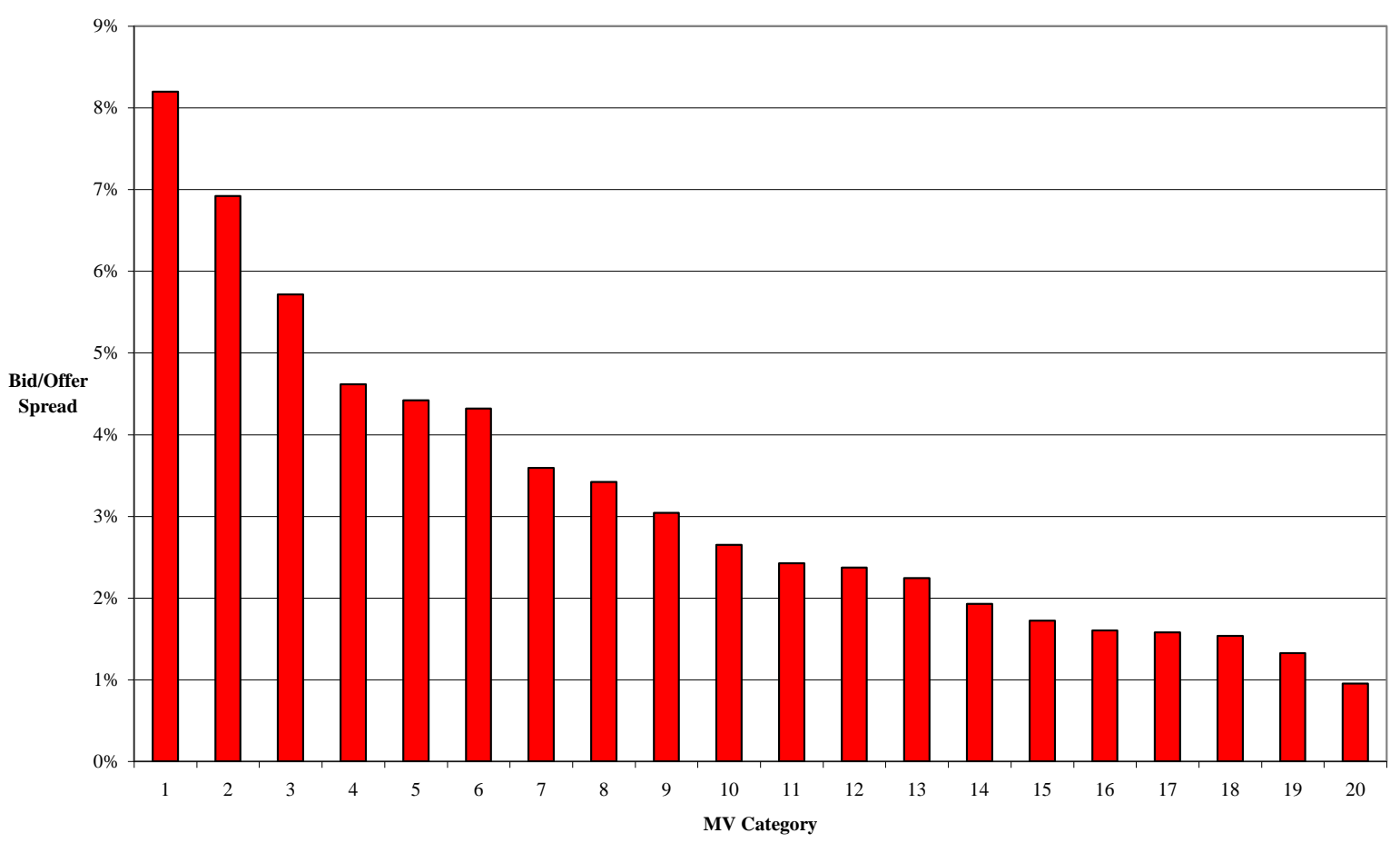

Figure 6: Portfolio values for the value and glamour deciles using EP1 and (EP1+EPM8) to sort companies into deciles, annual rebalancing, 1975-2003

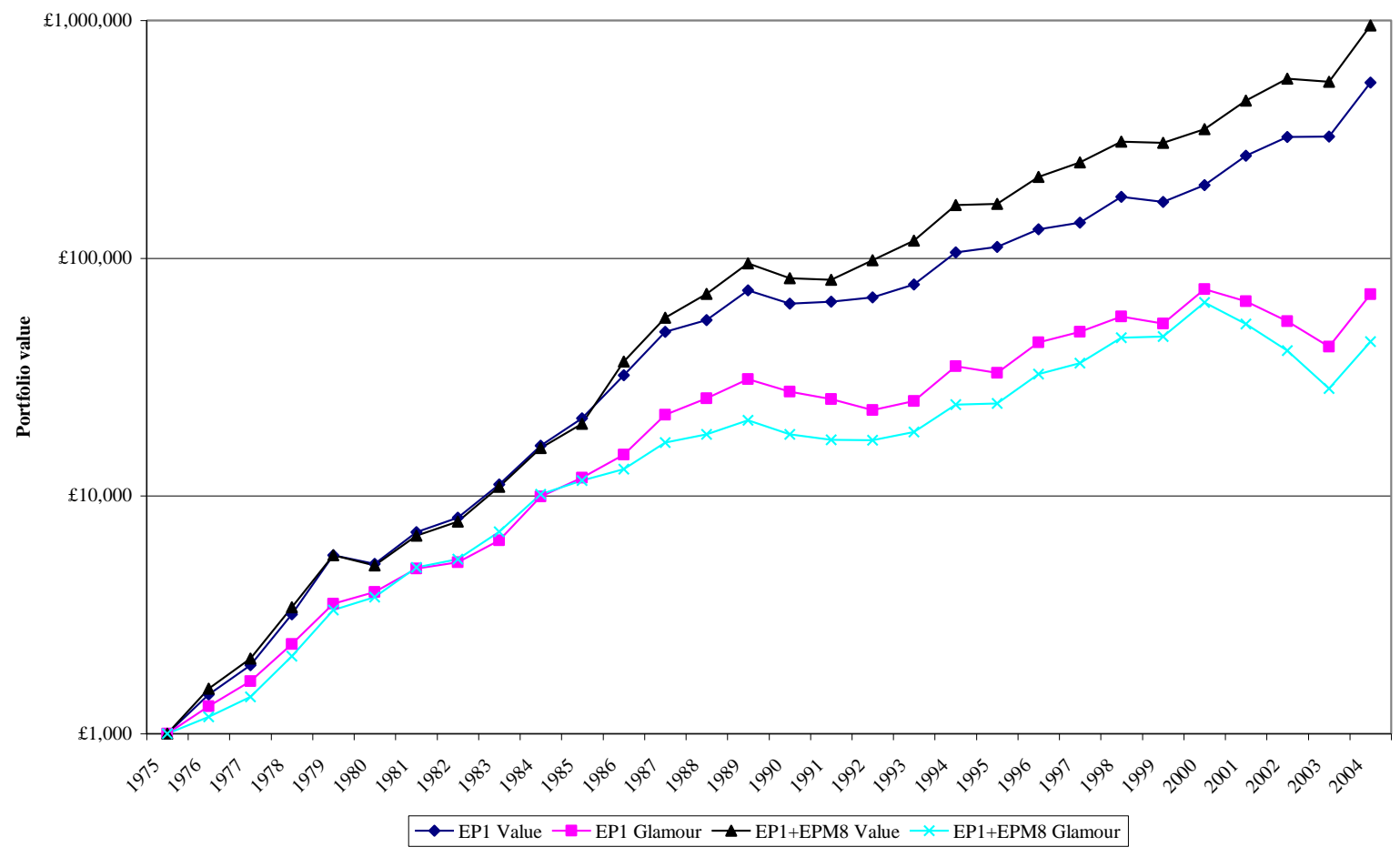

